\title{
The influence of dietary fat on postprandial lipaemia and factor VII coagulant activity in human subjects
}

\author{
BY N. YAHIA* AND T. A. B. SANDERS \\ Nutrition, Food and Health Research Centre, King's College London, Campden Hill Road, \\ London W8 7AH
}

Factor VII coagulant activity (FVIIc) is a potent risk factor for heart disease. The Northwick Park Heart Study (NPHS) found that elevated levels of FVIIc are associated with increased risk of fatal IHD, particularly in men over the age of 55 years and this association was stronger than that for plasma cholesterol (Meade et al. 1986). Subsequent studies have confirmed this association (Meade et al. 1993).

Factor VII is a key factor in the coagulation cascade. The coagulant glycoprotein factor VII circulates as a single-chain zymogen at a concentration of about $450 \mathrm{ng} / \mathrm{ml}$ with about $4 \mathrm{ng} / \mathrm{ml}$ present in normal plasma as an activated two-chain form, factor VIIa (FVIIa; Broze, 1994). The coagulation cascade can be initiated when FVIIa forms a complex with its cofactor, tissue factor (TF). The FVIIa-TF complex then cleaves factors IX and X to their active enzymes (IXa and Xa respectively), thereby inducing the conversion of prothrombin (Davie, 1995). In the presence of TF and a physiological concentration of $\mathrm{Ca}^{2+}$, factor $\mathrm{Xa}$ can activate the single-chain factor VII, thus accelerating the generation of prothrombin. FVIIa can also be generated in the absence of TF by enzymes involved in the contact system of coagulation, factors XIIa or IXa. The contact system can be activated in vitro when citrated plasma is incubated in the presence of a negatively-charged surface such as glass. During incubation of citrated plasma in the presence of a contact surface, the activation of factor XII and the sequential activation of factors XI and IX results in activation of factor VII (Thomson, 1980). There are several measurements of factor VII which need describing. Plasma FVIIc can be measured in the presence of TF and an appropriate factor VII-deficient substrate such that the test plasma's FVIIa is rate-limiting, and related to the recorded clotting time. FVIIc and FVIIa are not synonymous. FVIIa is quantitative, whereas FVIIc is qualitative and is influenced also by the concentration of factor VII zymogen. In practice, most studies have measured FVIIc.

A striking feature of FVIIc is its positive association with plasma triacylglycerol (TAG) concentration (Table 1). Treatment of hypertriacylglycerolaemia leads to a fall in FVIIc (Elkeles et al. 1980; Simpson et al. 1983; Andersen et al. 1990). This suggests that the relationship is causal. Thus, a fat-rich meal is frequently followed by transient increases in the levels of plasma TAG and FVIla without any change in the factor VII zymogen concentration (Sanders et al. 1996). However, when the diet is habitually rich in fat, an increase in the fasting level of factor VII zymogen also occurs (Miller et al. 1986, 1989). 


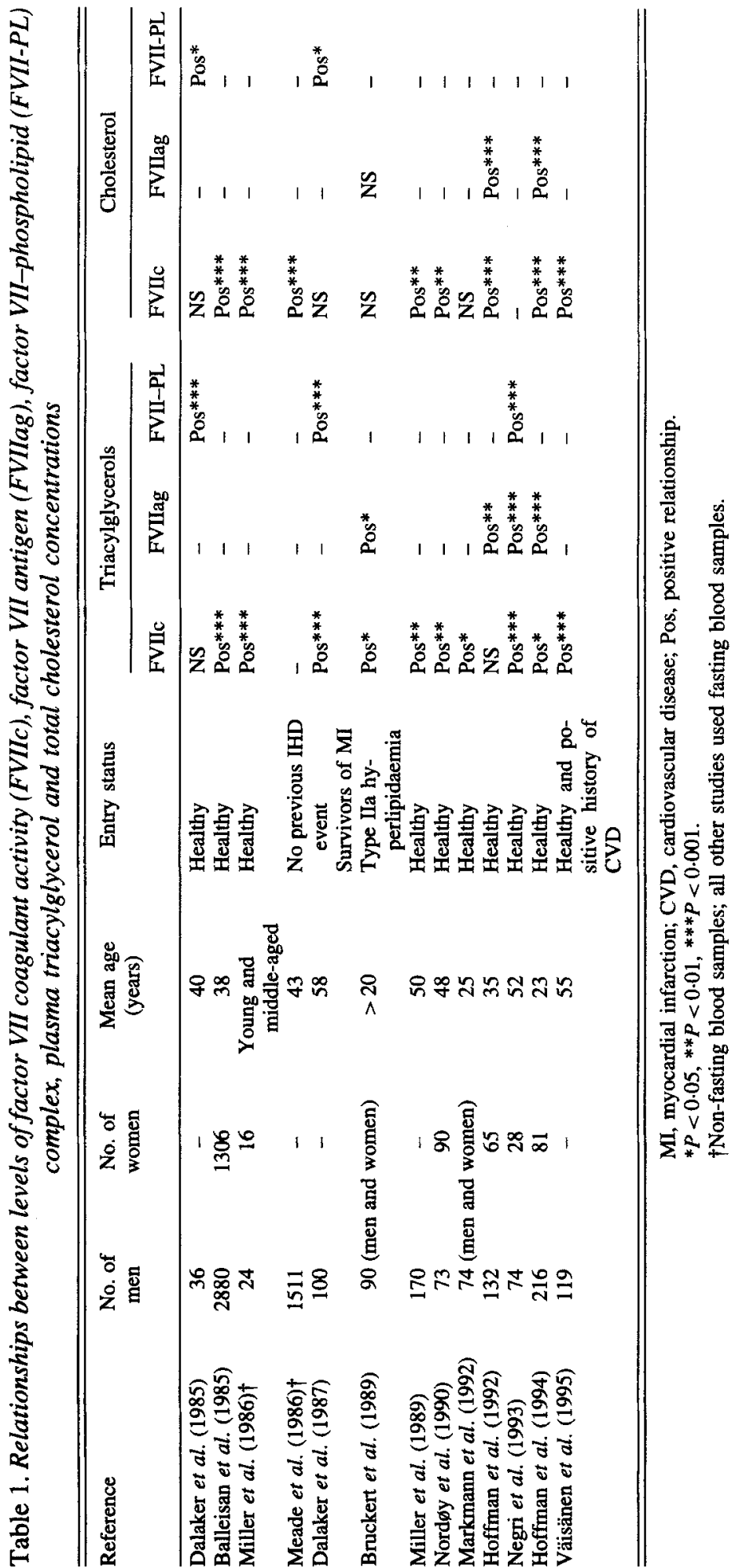


Table 2. Comparison of feeding trials on factor VII levels

\begin{tabular}{|c|c|c|c|c|}
\hline Study & Subjects & Diets & Duration & Results \\
\hline $\begin{array}{l}\text { Miller et al. } \\
\quad(1986)\end{array}$ & $\begin{array}{l}\text { Six healthy men and } \\
\text { women }\end{array}$ & $\begin{array}{l}\text { Two diets consisted of } \\
\text { low-fat diet }(13 \% \text { en- } \\
\text { ergy from fat; } 9.3 \mathrm{MJ}) \\
\text { and high-fat diet } \\
(62 \% \text { energy from fat; } \\
12.0 \mathrm{MJ})\end{array}$ & $\begin{array}{l}\text { Each diet was } \\
\text { consumed } \\
\text { for } 2 \text { weeks }\end{array}$ & $\begin{array}{l}\text { Plasma FVIIc and } \\
\text { plasma factor VII } \\
\text { concentration } \\
\text { were on average } 8 \\
\text { and } 19 \% \text { higher } \\
\text { respectively on the } \\
\text { high-fat diet than } \\
\text { on the low-fat diet }\end{array}$ \\
\hline $\begin{array}{l}\text { Markmann et al. } \\
\quad(1990)\end{array}$ & $\begin{array}{l}\text { Eleven healthy men } \\
\text { and women }\end{array}$ & $\begin{array}{l}\text { Two diets consisted of } \\
32 \% \text { energy from fat, } \\
\text { with a low or high } \\
\text { polyunsaturated:satu- } \\
\text { rated fatty acid ratio } \\
(0.28 \text { and } 0.89 \text { re- } \\
\text { spectively) with total } \\
\text { energy of } 10.7 \mathrm{MJ}\end{array}$ & $\begin{array}{l}\text { Each diet was } \\
\text { consumed } \\
\text { for } 2 \text { weeks }\end{array}$ & $\begin{array}{l}\text { The state of activa- } \\
\text { tion of factor VII } \\
\text { was not affected } \\
\text { by the change in } \\
\text { the dietary fat fol- } \\
\text { lowing both diets }\end{array}$ \\
\hline $\begin{array}{l}\text { Miller et al. } \\
\quad \text { (1991) }\end{array}$ & $\begin{array}{l}\text { Nine healthy adults } \\
\text { (five men, four } \\
\text { women) }\end{array}$ & $\begin{array}{l}\text { Two diets consisted of } \\
\text { about } 40 \% \text { energy } \\
\text { from fat, with a low or } \\
\text { high polyunsaturated: } \\
\text { saturated fatty acids } \\
\text { ratio ( }<0.3 \text { and }>0.3 \\
\text { respectively) with to- } \\
\text { tal energy of } 8.5 \mathrm{MJ}\end{array}$ & $\begin{array}{l}\text { Each diet was } \\
\text { consumed } \\
\text { for } 1 \text { week }\end{array}$ & $\begin{array}{l}\text { Dietary fat composi- } \\
\text { tion did not infiu- } \\
\text { ence FVIIc or } \\
\text { FVIIag levels }\end{array}$ \\
\hline $\begin{array}{l}\text { Tholstrup et al. } \\
\text { (1994) }\end{array}$ & $\begin{array}{l}\text { Fifteen young } \\
\text { healthy men }\end{array}$ & $\begin{array}{l}\text { Three isoenergetic diets: } \\
\text { shea butter ( } 42 \% \text { en- } \\
\text { ergy from fat, was rich } \\
\text { in stearic acid), palm } \\
\text { oil ( } 43 \% \text { energy from } \\
\text { fat, was rich in palmi- } \\
\text { tic acid), or palm-ker- } \\
\text { nel oil with high-oleic } \\
\text { sunflower oil ( } 35 \% \\
\text { energy from fat, was } \\
\text { rich in myristic and } \\
\text { lauric acids; } 10 \text { and } \\
30 \text { g/100g fatty acids } \\
\text { respectively) with to- } \\
\text { tal energy of } 14.4 \mathrm{MJ}\end{array}$ & $\begin{array}{c}\text { Each diet was } \\
\text { consumed } \\
\text { for } 3 \text { weeks }\end{array}$ & $\begin{array}{l}\text { The diet enriched } \\
\text { with stearic acid } \\
\text { resulted in } 13 \% \\
\text { lower FVIIc levels }\end{array}$ \\
\hline $\begin{array}{l}\text { Markmann et al. } \\
\text { (1994) }\end{array}$ & $\begin{array}{l}\text { Twenty-one healthy } \\
\text { middle-aged indi- } \\
\text { viduals (ten men, } \\
\text { eleven women) }\end{array}$ & $\begin{array}{l}\text { Two diets consisted of } \\
\text { low-fat diet }(28 \% \text { of } \\
\text { energy and } 3.3 \mathrm{~g} \text { fibre/ } \\
\text { MJ, } 10.4 \mathrm{MJ} / \mathrm{d}) \text { and } \\
\text { Danish diet }(39 \% \text { of } \\
\text { energy and } 2.1 \mathrm{~g} \text { fibre/ } \\
\text { MJ, } 10.5 \mathrm{MJ} / \mathrm{d})\end{array}$ & $\begin{array}{l}\text { Each diet was } \\
\text { consumed } \\
\text { for } 2 \text { weeks }\end{array}$ & $\begin{array}{l}\text { The low-fat diet } \\
\text { lowered plasma } \\
\text { FVIIc activity le- } \\
\text { vel by } 8 \% \text { ( } 88 \% \\
\text { on low-fat diet } v \text {. } \\
96 \% \text { on high-fat } \\
\text { diet) and FVIIag } \\
\text { by } 4 \% \text {. }\end{array}$ \\
\hline
\end{tabular}

FVIIc, factor VII coagulant activity; FVIIag, factor VII antigen.

\section{INFLUENCE OF DIETARY FAT CONTENT OR POLYUNSATURATED FATTY ACIDS:SATURATED FATTY ACIDS ON POSTPRANDIAL LIPAEMIA AND FACTOR VII}

A summary of the studies on the influence of dietary fat composition on factor VII is presented in Table 2. The main finding from most of these studies is that factor VII levels are not affected by polyunsaturated fatty acids:saturated fatty acids per se. 
Table 3. Influence of eicosapentaenoic acid (EPA) and docosahexaenoic acid (DHA) from fish and fish oil supplementations on factor VIIc

\begin{tabular}{|c|c|c|c|c|c|c|c|c|c|}
\hline \multirow[t]{2}{*}{ Study } & \multicolumn{2}{|c|}{$\begin{array}{l}\text { No. of } \\
\text { men }\end{array}$} & \multicolumn{2}{|c|}{$\begin{array}{l}\text { No. of } \\
\text { women }\end{array}$} & \multirow[t]{2}{*}{$\begin{array}{l}\text { Mean age } \\
\text { (years) }\end{array}$} & \multirow[t]{2}{*}{ Entry status } & \multirow[t]{2}{*}{$\begin{array}{l}\text { Duration of } \\
\text { test period }\end{array}$} & \multirow{2}{*}{$\begin{array}{c}\text { EPA + } \\
\text { DHA } \\
\text { dose }(g)\end{array}$} & \multirow[t]{2}{*}{$\begin{array}{l}\text { Effects on } \\
\text { FVIIc }\end{array}$} \\
\hline & $\mathrm{T}$ & $\mathrm{C}$ & $\mathrm{T}$ & $\mathrm{C}$ & & & & & \\
\hline Sanders et al. (1981) & 12 & & - & & 23 & Healthy & 6 weeks & 3 & NS \\
\hline Haines et al. (1986) & 14 & 5 & 16 & 6 & 42 & Diabetic & 6 weeks & 4.6 & NS \\
\hline Sanders (1987) & 12 & 12 & - & & - & Healthy & 6 weeks & 4 & NS \\
\hline Muller et al. (1989)* & 40 & 42 & - & & 28 & Healthy & 6 weeks & 4.7 & NS \\
\hline Schmidt et al. (1989) & 9 & & 8 & & 45 & Hyperlipidaemia & 6 weeks & 6 & NS \\
\hline \multirow[t]{3}{*}{ Schmidt et al. (1990) } & 10 & & - & & 34 & Healthy & 6 weeks & $1 \cdot 3$ & NS \\
\hline & 10 & & - & & 34 & Healthy & 6 weeks & 4 & NS \\
\hline & 10 & & - & & 34 & Healthy & 6 weeks & 9 & NS \\
\hline Hendra et al. (1990) & 30 & 25 & 10 & 15 & 55.9 & Diabetic & 6 weeks & 3 & $+19.3 \%$ \\
\hline Markmann et al. (1991)* & 12 & & - & & - & Healthy & $10 \mathrm{~d}$ & 3.4 & NS \\
\hline Møller et al. (1992) & 10 & 10 & 10 & 10 & 34.5 & Healthy & Single dose & 13.6 & NS \\
\hline Boberg et al. (1992) & 12 & & 2 & & 65 & Diabetic & 8 weeks & 3 & NS \\
\hline Schmidt et al. (1992) & 10 & & 14 & & 39.5 & Healthy & 9 months & $3 \cdot 2$ & NS \\
\hline Sanders et al: (1997) & 26 & & - & & 23 & Healthy & 3 weeks & 5 & $+7 \%$ \\
\hline
\end{tabular}

T, treatment group; $\mathrm{C}$, control group.

*Fish-diet trials; the rest were fish-oil trials.

\section{INFLUENCE OF $n$ - 3 FATTY ACIDS ON POSTPRANDIAL ACTIVATION OF FACTOR VII}

It has been suggested that the consumption of fatty-fish or fish-oil supplements may affect blood coagulation factors. Most studies have not had sufficient statistical power to detect a change and failed to demonstrate any effect of fish oils on FVIIc (Table 3). However, two studies (Hendra et al. 1990; Sanders et al. 1997) using the NPHS assay have found an increase in FVIIc. These observations are unexpected since long-chain $n-3$ fatty acids decrease plasma TAG concentrations.

We have also examined the acute effects of fish oil (MaxEPA; Seven Seas Ltd) on postprandial activation of factor VII (Yahia \& Sanders, 1996). Four isoenergetic test meals were administered to twelve subjects in a randomized block design. The test meals consisted of $90 \mathrm{~g}$ olive oil, $75 \mathrm{~g}$ olive oil $+15 \mathrm{~g}$ MaxEPA, $15 \mathrm{~g}$ olive oil or $15 \mathrm{~g}$ MaxEPA. In this study, plasma TAG concentration was significantly elevated by the test meal with $90 \mathrm{~g}$ olive oil but not by the test meal with the admixture of olive oil and fish oil (Table 4). The low-fat test meals did not lead to an increase in postprandial lipaemia, and there were no differences between the test meals with olive oil and fish oil. FVIIc was significantly elevated by $90 \mathrm{~g}$ fat loads but not by $15 \mathrm{~g}$ test meals at 3 and $7 \mathrm{~h}$. Despite the lower degree of postprandial lipaemia following the test meal with the admixture of olive oil and fish oil, the degree of factor VII activity was similar to that of the test meal with olive oil. This elevation of FVIIc by $n-3$ fatty acids with decreased lipaemia might be due to an increase in the rate of lipolysis which acts as a catalyst for activation of factor VII.

In this study, despite the lower degree of postprandial lipaemia following $n-3$ fatty acids, factor VII activity levels were not reduced. It is proposed that $n-3$ fatty acids increase the rate of lipolysis, thus leading to the generation of remnant particles, which expose a large contact surface that may activate factor VII. 
Table 4. Plasma triacylglycerol (TAG) concentrations and factor VII coagulant activity (FVIIc) at 0,3 and $7 \mathrm{~h}$ following the test meals

(Mean values with their standard errors)

\begin{tabular}{|c|c|c|c|c|c|c|c|c|}
\hline \multirow[t]{2}{*}{ Test meal.... } & \multicolumn{2}{|c|}{$90 \mathrm{~g}$ olive oil } & \multicolumn{2}{|c|}{$\begin{array}{l}75 \mathrm{~g} \text { olive oil }+ \\
15 \mathrm{~g} \mathrm{MaxEPA}^{*}\end{array}$} & \multicolumn{2}{|c|}{$15 \mathrm{~g}$ olive oil } & \multicolumn{2}{|c|}{$15 \mathrm{~g} \mathrm{MaxEPA*}$} \\
\hline & $\overline{\text { Mean }}$ & $\mathrm{SE}$ & Mean & $\overline{S E}$ & Mean & $\overline{S E}$ & Mean & SE \\
\hline \multicolumn{9}{|c|}{ FVIIc (\% reference plasma) } \\
\hline $\mathrm{Oh}$ & 81 & 5.6 & 85 & 6.6 & 82 & $7 \cdot 4$ & 81 & 5.9 \\
\hline $3 h$ & $93^{2}$ & 5.6 & $94^{\mathrm{ab}}$ & $7 \cdot 5$ & $85^{\mathrm{cb}}$ & $8 \cdot 4$ & $82^{\mathrm{c}}$ & 5.4 \\
\hline $7 \mathrm{~h}$ & $93^{a}$ & 6.5 & $94^{b}$ & $8 \cdot 1$ & $83^{c}$ & 8.8 & $83^{c}$ & 7.8 \\
\hline \multicolumn{9}{|l|}{ TAG } \\
\hline AUC & $9.92^{\mathrm{a}}$ & 1.7 & $6 \cdot 91^{b}$ & 1.4 & $1.66^{\mathrm{c}}$ & 0.5 & $2 \cdot 17^{\mathrm{c}}$ & 0.8 \\
\hline
\end{tabular}

a,b,c Mean values in the same row with unlike superscript letters were significantly different $(P<0.05)$.

AUC, total area under the curve described by plasma TAG concentrations $v$. time to $7 \mathrm{~h}$.

*Seven Seas Ltd.

Table 5. Postprandial triacylglycerol concentrations and postprandial activation of factor VII following the test meals

\begin{tabular}{|c|c|c|c|c|}
\hline \multirow[t]{2}{*}{ Test meal... } & \multicolumn{2}{|c|}{$90 \mathrm{~g}$ olive oil } & \multicolumn{2}{|c|}{$90 \mathrm{~g} \mathrm{MCT}$} \\
\hline & Mean & SE & Mean & SE \\
\hline $\begin{array}{l}\text { Change from fasting triacylglycerol at } 3 \mathrm{~h}(\mathrm{mmol} / \mathrm{)}) \\
\text { Change from fasting FVIIc at } 7 \mathrm{~h} \text { (\% reference plasma) }\end{array}$ & $\begin{array}{l}1.58^{\mathrm{a}} \\
11.2^{\mathrm{b}}\end{array}$ & $\begin{array}{l}0.63 \\
3.28\end{array}$ & $\begin{array}{l}-0.14 \\
-0.6\end{array}$ & $\begin{array}{l}0 \cdot 07 \\
7.38\end{array}$ \\
\hline
\end{tabular}

a,b Mean values in the same column with unlike superscript letters were significantly different $(P<0.05)$.

MCT, medium-chain triacylglycerol; FVIIc, factor VII coagulant activity.

\section{DOES THE CHAIN LENGTH OF DIETARY FATTY ACIDS INFLUENCE POSTPRANDIAL LIPAEMIA AND FACTOR VII COAGULANT ACTIVITY?}

Only a few studies have examined the effect of fatty-acid chain length on FVIIc. Tholstrup et al. (1994), found that dietary stearic acid led to lower levels of FVIIc compared with palmitate or a mixture of myristic and lauric acids. We have found that medium-chain TAG (MCT) do not lead to activation of FVIIc (Yahia et al. 1995). In this study we compared two test meals containing either $90 \mathrm{~g}$ olive oil or $90 \mathrm{~g}$ MCT providing 5.6 MJ. Results showed that the plasma TAG concentration was significantly elevated during the test meal with olive oil, whereas such an effect was not noticed during the MCT test meal (Table 5). FVIIc was elevated at $7 \mathrm{~h}$ for the test meal with olive oil but not for the test meal with MCT. Thus, the activation of factor VII by the test meal with olive oil but not by the test meal with MCT would suggest that long-chain fatty acids which lead to chylomicron formation are able to activate factor VII in the postprandial state (Sanders et al. 1996).

\section{DOES THE PATTERN OF FAT INTAKE AFFECT FACTOR VII COAGULANT ACTIVITY LEVELS?}

It would be predicted that one very-high-fat meal would cause greater postprandial lipaemia and, thus, be more likely to increase FVIIc to a greater extent than if the fat was consumed in divided amounts. To investigate this hypothesis, the effect of a low fat intake 
and that of a high fat intake $(120 \mathrm{~g})$ consumed in a single meal or in three meals on plasma TAG concentration and FVIIc were compared. Results suggested that the pattern of fat intake might be as important as the total intake itself (Yahia et al. 1996).

\section{CONCLUSION}

FVIIc can be elevated in healthy subjects following consumption of relatively-large intakes of long-chain TAG, providing lipaemia is induced. Although postprandial lipaemia is reduced following the consumption of $n-3$ fatty acids, the degree of factor VII activation is not reduced. However, there are also a number of factors that influence postprandial lipaemia such as obesity, physical activity, age, gender and genotype (polymorphism in the factor VII gene). A common polymorphism in the factor VII gene has been found to affect FVIIc (Green et al. 1991). The base gene that causes polymorphism is G-to-A substitution in the second position of the codon for amino acid 353, which leads to the replacement of arginine by glutamine. This suggests that possession of the factor VII-Gln $\mathrm{G}_{353}$ allele is likely to confer protection by reducing the amount of FVIIa produced in response to fat intake. Future studies are needed to consider the influence of these factors on the postprandial activation of factor VII.

\section{REFERENCES}

Andersen, P., Smith, P., Seljeflot, I., Brataker, S. \& Arnesen, H. (1990). Effects of Gemfibrizol on lipids and haemostasis after myocardial infarction. Thrombosis and Haemostasis 63, 174-177.

Balleisen, L., Assman, G., Bailey, J., Epping, P. H., Schulte, H. \& De Loo, J. V. (1985). Epidemiological study on factor VII, factor VIII and fibrinogen in an industrial population: II. Baseline data on the relation to blood pressure, blood glucose, uric acid and lipid fractions. Thrombosis and Haemostasis 54, 721-723.

Boberg, M., Pollare, T., Siegbahn, A. \& Vessby, B. (1992). Supplementation with $n-3$ fatty acids reduces triglycerides but increases PAI-1 in non-insulin-dependent diabetes mellitus. European Journal of Clinical Investigation 22, 645-650.

Broze, G. J. (1994). The tissue factor pathway of coagulation: factor VII, tissue factor, and tissue factor inhibitor. In Haemostasis and Thrombosis, 3rd ed., pp. 349-377 [A. L. Bloom, C. D. Forbes, D. P. Thomas and E. G. D. Tuddenham, editors]. London: Churchill Livingstone.

Bruckert, E., de Sousa, J. C., Giral, P., Sorai, C., Chapman, M. J., Caen, J. \& de Gennes, J. L. (1989). Interrelationship of plasma triglyceride and coagulant factor VII levels in normotriglyceridaemic hypercholesterolemia. Atherosclerosis 75, 129-134.

Dalaker, K., Hjerman, I. \& Prydz, H. (1985). A novel form of factor VII in plasma from men at risk for cardiovascular disease. British Journal of Haematology 61, 315-322.

Dalaker, K., Smith, P., Arnesen, H. \& Hrydz, H. (1987). Factor VII-phospholipid complex in male survivors of acute myocardial infarction. Acta Medica Scandinavica 222, 111-116.

Davie, E. W. (1995). Biochemical and molecular aspects of the coagulation cascade. Thrombosis and Haemostasis 74, 1-6.

Elkeles, R. S., Chakrabarti, R., Vickers, M., Stirling, Y. \& Meade, T. W. (1980). Effect of treatment of hyperlipidaemia on haemostatic variables. British Medical Journal 281, 973-974.

Green, F., Kelleher, C., Wilkes, H., Temple, A., Meade, T. W. \& Humphries, S. (1991). A common genetic polymorphism associated with lower coagulation factor VII levels in healthy individuals. Arteriosclerosis and Thrombosis 11, 540-546.

Haines, A. P., Sanders, T. A. B., Imeson, J. D., Mahler, R. F., Martin, J., Mistry, M., Vickers, M. \& Wallace, P. G. (1986). Effects of a fish oil supplement on platelet function, haemostatic variables and albuminuria in insulin-dependent diabetics. Thrombosis Research 43, 643-655.

Hendra, T. J., Britton, M. E., Roper, D. R., Wagaine-Twabwe, D., Jeremy, J. Y., Dandona, P., Haines, A. P. \& Yudkin, J. S. (1990). Effects of fish oil supplements in NIDDM subjects. Diabetes Care 13, 821-829.

Hoffman, C. J., Lawson, W. E., Miller, R. H. \& Hultin, M. B. (1994). Correlation of vitamin K-dependent clotting factors with cholesterol and triglycerides in healthy young adults. Arteriosclerosis and Thrombosis 14, $1737-1740$.

Hoffman, C. J., Miller, R. H. \& Hultin, M. B. (1992). Correlation of factor VII activity and antigen with cholesterol and triglycerides in healthy young men. Arteriosclerosis and Thrombosis 12, 267-270. 
Markmann, P., Jespersen, J., Leth, T. \& Sandström, B. (1991). Effects of a fish diet versus a meat diet on blood lipids, coagulation, and fibrinolysis in healthy young men. Journal of Internal Medicine 229, 317-323.

Markmann, P., Sandström, B. \& Jespersen, J. (1990). Effects of total fat content and fatty acid composition in diet on factor VII coagulant activity and blood lipids. Atherosclerosis 80, 227-233.

Markmann, P., Sandström, B. \& Jespersen, J. (1992). Fasting blood coagulation and fibrinolysis of young adults unchanged by reduction in dietary fat content. Arteriosclerosis and Thrombosis 12, 201-205.

Markmann, P., Sandström, B. \& Jespersen, J. (1994). Low-fat high fibre diet favourably affects several independent risk markers of ischaemic heart disease. Observations on blood lipids and coagulation, and fibrinolysis from a trial of middle-aged Danes. American Journal of Clinical Nutrition 59, 935-939.

Meade, T. W., Brozovic, M., Chakrabarti, R., Haines, A. P., Imeson, J. D., Mellows, S., Miller, G. J., North, W. R. S., Stirling, Y. \& Thompson, S. G. (1986). Haemostatic function and ischaemic heart disease: principal results of the Northwick Park Heart Study. Lancet ii, 533-537.

Meade, T. W., Ruddock, V., Stirling, Y., Chakrabarti, R. \& Miller, G. (1993). Fibrinolytic activity, clotting factors, and long-term incidence of ischaemic heart disease in Northwick Park Heart Study. Lancet 342, 10761079.

Miller, G. J., Cruickshank, J. K., Ellis, L. J., Thompson, R. L., Wilkes, H. C., Stirling, Y., Mitropoulos, K. A., Allison, J. V., Fox, T. E. \& Walker, A. O. (1989). Fat consumption and factor VII coagulant activity in middle-aged men. An association between a dietary and thrombogenic coronary risk factor. Atherosclerosis 78, 19-24.

Miller, G. J., Martin, J. C., Webster, J., Wilkes, H., Miller, N. E., Wilkinson, W. H. \& Meade, T. W. (1986). Association between dietary fat intake and factor VII coagulant activity- a predictor of cardiovascular mortality. Atherosclerosis 60, 269-277.

Miller, G. J., Wilkes, H. C., Meade, T. W., Bauer, K. A., Barzegar, S. \& Rosenberg, R. D. (1991). Haemostatic changes that constitute the hypercoagulable state. Lancet 338, 1079.

Møller, J. M., Svaneborg, N., Lervang, H. H., Varming, K., Madsen, P., Dyerberg, J. \& Schmidt, E. B. (1992). The acute effect of a single very high dose of $n-3$ fatty acids on coagulation and fibrinolysis. Thrombosis and Haemostasis 67, 569-577.

Muller, A. D., van Houwelingen, A. C., van Dam-Mieras, M. C. E., Bas, B. M. \& Hornstra, G. (1989). Effect of a moderate fish intake on haemostatic parameters in healthy males. Thrombosis and Haemostasis 61 , $468-473$.

Negri, M., Arigliano, P. L., Talamini, G., Carlini, S., Manzato, F. \& Bonadonna, G. (1993). Levels of plasma factor VII and factor VII activated forms as a function of plasma triglyceride levels. Atherosclerosis $99,55-$ 61.

Nordøy, A., Illingworth, D. R., Connor, W. E. \& Goodnight, S. (1990). Increased activity of factor VII and factor VII-phospholipid complex measured using a normotest system in subjects with hyperlipidaemia. Haemostasis 20, 65-72.

Sanders, T. A. B. (1987). Influence of moderate intakes of fish oil on blood lipids. Proceedings of the AOCS Short Course on Polyunsaturated Fatty Acids and Eicosanoids, pp. 70-86 [W. E. M. Lands, editor]. Champaign, IL: AOCS.

Sanders, T. A. B., Miller, G. J., De Grassi, T. \& Yahia, N. (1996). Post-prandial activation of coagulant factor VII by long-chain dietary fatty acids. Thrombosis and Haemostasis 76, 369-371.

Sanders, T. A. B., Oakley, F. R., Miller, G. J., Mitropoulos, K., Crook, D. \& Oliver, M. F. (1997). A comparison of the influence of long-chain $n-3$ with linoleic acid in diets low in saturated fatty acids on plasma lipoproteins and haemostatic variables. Arteriosclerosis Thrombosis and Vascular Biology (In the Press).

Sanders, T. A. B., Vickers, M. \& Haines, A. P. (1981). Effect on blood lipids and haemostasis of a supplement cod-liver oil, rich in eicosapentaenoic and docosahexaenoic acids, in healthy young men. Clinical Science 61, 317-324.

Schmidt, E. B., Ernst, E., Varming, K., Pedersen, J. O. \& Dyerberg, J. (1989). The effect of $n-3$ fatty acids on lipids and haemostasis in patients with type Ila and type IV hyperlipidaemia. Thrombosis and Haemostasis 62, 797-801.

Schmidt, E. B., Lervang, H. H., Varming, K., Madsen, P. \& Dyerberg, J. (1992). Long-term supplementation with $n-3$ fatty acids on lipids and haemostasis and blood pressure. Scandinavian Journal of Clinical and Laboratory Investigation 52, 221-228.

Schmidt, E. B., Varming, K., Ernst, E., Madsen, P. \& Dyerberg, J. (1990). Dose-response studies on the effect of $n-3$ polyunsaturated fatty acids on lipids and haemostasis. Thrombosis and Haemostasis 63, 1-5.

Simpson, H. C. R., Mann, J. I., Meade, T. W., Chakrabarti, R., Stirling, Y. \& Woolf, L. (1983). Hypertriglyceridaemia and coagulability. Lancet i, 786-789.

Tholstrup, T., Marckmann, P., Jespersen, J. \& Sandström, B. (1994). Fat high in stearic acid favourably affects blood lipids and factor VII coagulant activity in comparison with fats high in palmitic acid or high in myristic and lauric acids. American Journal of Clinical Nutrition 59, 371-377.

Thomson, M. (1980). Blood Coagulation and Haemostasis. A Practical Guide. 2nd ed. London: Churchill Livingstone.

Väisänen, S., Rankin, T. \& Pentilä, R. (1995). Factor VII coagulant activity in relation to serum lipoproteins and dietary fat in middle-aged men. Thrombosis and Haemostasis 73, 435-438. 
Yahia, N. \& Sanders, T. A. B. (1996). Influence of $n-3$ fatty acids on postprandial lipaemia and factor VII coagulant activity. Proceedings of the Nutrition Society 55, 173A.

Yahia, N., Sanders, T. A. B. \& Miller, G. (1995). Long-chain but not medium-chain triacylglycerols increase factor VII coagulant activity. Proceedings of the Nutrition Society 54, 147A.

Yahia, N., Songhurst, C. \& Sanders, T. A. B. (1996). Effect of different patterns of fat intake on postprandial lipaemia and factor VII coagulant activity. Proceedings of the Nutrition Society 55, 227A. 